\title{
Prediksi Merapi, Menduga Gempa
}

Oleh Gede H. Cahyana

Dimuat di HU Pikiran Rakyat,30 Mei 2006.

Gempa Yogyakarta takkan menelan korban jiwa jika bisa diduga jauh-jauh hari sebelumnya seperti halnya erupsi Merapi. Sampai saat ini erupsi Merapi belum memakan korban jiwa meskipun berkali-kali lava pijarnya meluncur dan wedhus gembelnya merayapi lereng. Mudah-mudahan takkan ada korban apa pun apalagi korban jiwa. Tapi sebaliknya, dalam tempo satu menit saja, gempa Yogya per 28 Mei, pk. 18.00 WIB sudah menewaskan 3.400-an orang, 2.000-an luka berat dan 1.500-an luka ringan. Rugi harta benda tak terhitung jumlahnya sebab mayoritas bangunan, terutama di Bantul, tinggal puing-puingnya.

\section{Prediksi Merapi}

Dari dua peristiwa tersebut muncullah 'dogma' bahwa bencana alam yang tinggi frekuensinya, seperti letusan Merapi, dampaknya relatif kecil, cenderung diabaikan. Malah fenomena letusannya dijadikan objek wisata, dijual kepada turis sekaligus menjadi objek studi. Tak demikian dengan bencana alam yang jarang terjadi, seperti gempa Yogya, dampaknya bisa sangat buruk, korban jiwa dan hartanya banyak. Merapi adalah contoh menarik. Sejak dulu penduduk di sekitar Merapi enggan dievakuasi walaupun statusnya awas. Dalam taraf awas saja mereka tak hendak mengungsi, apatah lagi dalam taraf siaga. Ditambah lagi ada kepercayaan lokal turuntemurun yang menganggap Merapi punya kekuatan supranatural dan mereka sudah hafal kapan Merapi bakal meletus serius dan kapan hanya batuk-batuk kecil. Yang seperti ini memang sulit dijelaskan dengan logika orang-orang 'terdidik'.

Masyarakat di sekitar Merapi tak mau percaya begitu saja kepada pakar sehingga banyak yang enggan dievakuasi dan lebih memilih menjaga ternak dan rumahnya. Sampai taraf awas pun mereka tak mau diungsikan. Malah ketika Merapi sedang aktifaktifnya meletus, ada yang justru kembali ke rumahnya dan menengok ternak dan kebunnya. Apakah mereka tak sayang nyawanya? Tentu saja mereka sayang. Tapi masalahnya, mereka meragukan kredibilitas pakar yang dianggap orang pemerintah, sarat dengan kebohongan dan munafik serta bukan suruhan raja atau Sri Sultan. Kepercayaan seperti ini masih ada. Masyarakat lebih percaya pada pemimpin informalnya ketimbang pejabat negara. Apalagi terhadap orang yang dianggap juru kunci Merapi, mereka percaya total kepadanya. Oleh sebab itu, kapasitas seorang pejabat dan seorang pakar gunung api harus betul-betul tinggi agar setiap prediksinya mendekati kenyataan sehingga dipercayai oleh penduduk.

Lain Merapi, lain pula gempa . Ketika orang-orang di lereng Merapi waswas akan lava pijar dan uap panasnya, orang-orang yang tinggal jauh di Selatan Merapi mungkin merasa tak diintai bahaya dan merasa beruntung tinggal jauh dari Merapi. Namun apa nyana, gempa tektonik 5,9 skala Richter datang tiba-tiba bakda fajar selama 57 detik dan menggelar bencana yang jauh lebih parah daripada erupsi Merapi. Areanya luas, mulai dari bibir pantai sampai ke Magelang dan Klaten serta merusak candi Brahma, salah satu candi di situs candi Prambanan. Tak ada pakar yang menduga dengan presisi tinggi kapan suatu gempa akan terjadi. Jangankan memastikan dalam ukuran hari, jam, atau menit-detik, memastikan dalam ukuran bulan saja sulitnya bukan main. 


\section{Menduga gempa}

Sekuensial erupsi Merapi sungguh menarik. Dimulai dari getaran yang hanya terdeteksi seismograf, terjadi intrusi magma, perluasan kubah, longsoran, erupsi awal dan lateral, lalu erupsi vertikal tapi tak terlalu kuat. Pertanyaannya, bisakah hal serupa terjadi pada gempa? Bisakah pakar gempa memberikan sinyal awal akan terjadi gempa? Di atas telah dijawab, tidak bisa! Ini pun sudah ditegaskan ketika ada konferensi tentang upaya peringatan dini tsunami. Kenapa bukan peringatan dini gempa? Sebab, gempa tak bisa diprediksi. Gempa Aceh dan Yogya adalah buktinya, datang diam-diam, pada pagi-pagi setelah fajar menyingsing. Tapi ini ada 'untungnya', sebab jika terjadi dini hari ketika banyak yang tidur nyenyak maka korbannya akan lebih banyak lagi.

Namun demikian, walaupun sulit dideteksi, ada sejumlah indikasi yang dianggap mengawali gempa. Misalnya, emisi gas radon dari sumur-sumur (pada kasus Merapi, seberapa banyakkah radon yang diemisikan dan bagaimana caranya mengetahui dan mengukurnya?), kenaikan abnormal muka tanah, hewan air dan darat berperilaku aneh dan panik. Tingkah hewan ini menyiratkan gempa akan terjadi beberapa saat lagi. Khusus untuk anomali kenaikan muka tanah, mari dilihat kasus di Niigata, Jepang. Proses gempa sudah dimulai sepuluh tahun sebelum hari H. Muka tanah di daerah pantai Nezugasaki di Timur Laut Niigata naik setinggi $12 \mathrm{~cm}$ lalu turun lagi menjadi 8 cm sebelum terjadi gempa. Begitu pun di sepanjang pantai Selatan dari Nezugasaki menuju Niigata. Sedangkan di Selatan Niigata, muka tanahnya justru turun antara 4 sampai $12 \mathrm{~cm}$. Akhirnya, pada 1964 terjadilah gempa yang episenternya di Laut Jepang, di dekat Pulau Awashima sekuat 7,5 skala Richter.

Rentang waktu indikator gempa tersebut memang lama, sepuluh tahun. Di sinilah peran pakar gempa dalam menduga fenomena awal sebelum gempa dan berani memprediksikan kapan terjadinya sekaligus bertanggung jawab. Kredibilitas adalah taruhannya. Apabila sekelompok pakar gempa memprediksi akan terjadi gempa di laut kidul menyusul erupsi Merapi (terlepas dari ada tidaknya kaitan antara erupsi dan gempa itu) tentu kredibilitasnya kian tinggi. Masalahnya adalah ketika prediksinya meleset dalam jangka panjang, misalnya satu-dua tahun apalagi sepuluh tahun, maka hancurlah kepakarannya. Di sinilah pakar gempa merasa berada di simpang jalan. Itu sebabnya jarang pakar gempa berani menyatakan dengan lugas di media massa bahwa akan ada gempa di suatu tempat dengan waktu yang pasti. Mereka sebetulnya sudah menduga, tapi entah kapan waktunya, akan terjadi gempa di Selatan Jawa pascatsunami Aceh. Ternyata betul. Satu setengah tahun sejak gempa Aceh itu terjadilah gempa yang episenternya di laut kidul.

Artinya, data duga gempa sangat berguna bagi masyarakat dan pemerintah. Data ini bisa digunakan untuk membuat rencana pembangunan wilayah, tujuan wisata, dan kegiatan bisnis termasuk persiapan lokasi evakuasi. Bagaimanapun, peringatan dini gempa dan erupsi sangat bermanfaat sehingga upaya keras mesti ditempuh agar mampu memprediksi bencana demi mengurangi jumlah korban. Apapun caranya harus ditempuh. Maka, jika peringatan dini sudah melalui kajian saintifik, masyarakat janganlah menyalahkan pakar. Terjadi atau tidak adalah soal kedua. Yang pertama adalah soal adanya peringatan dini lewat kajian saintifik dan diputuskan oleh pemerintah. Anggap saja ini prakiraan gempa yang serupa dengan prakiraan cuaca. Kita biasa mendengar prakiraan cuaca bahwa di suatu tempat akan hujan. Andai pun tidak hujan, tak perlulah marah-marah. Tak rugilah orang-orang yang bersedia payung meskipun tak jadi hujan. Bisakah hal serupa itu diterapkan pada gempa?* 